\title{
Animal Blood Product-Derived Intermediate Paste Production
}

National Cancer Institute

\section{Source}

National Cancer Institute. Animal Blood Product-Derived Intermediate Paste Production.

NCl Thesaurus. Code C112929.

The production of concentrated proteins from animal plasma during a protein purification process. 